\title{
IMPLEMENTATION IMPACTS OF PRL METHODOLOGY (U)
}

\section{FEBRUARY 1993}

Nuclear Materials Planning Support

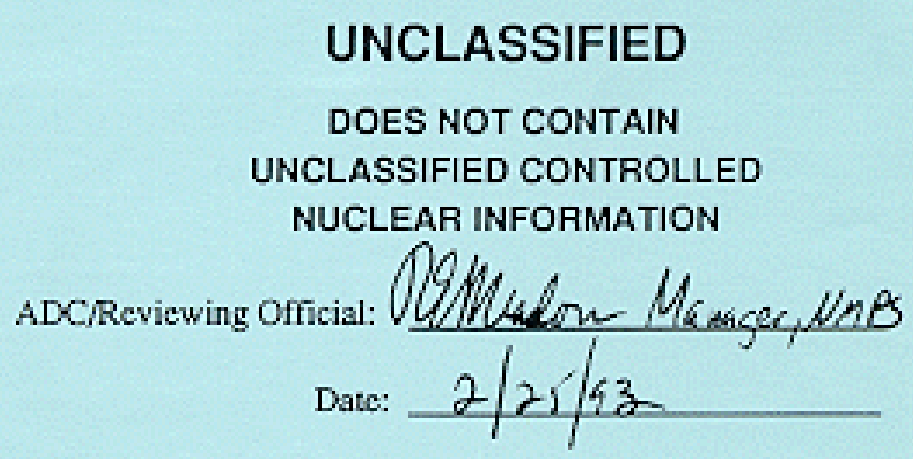

Prepared for the U.S. Department of Energy under Contract DE-AC09-89SR 18035

\section{Westinghouse Savannah River Company}

Savannah River Site

Aiken, SC 29808 


\section{DISCLAIMER}

This report was prepared as an account of work sponsored by an agency of the United States Government. Neither the United States Government nor any agency thereof, nor any of their employees, makes any warranty, express or implied, or assumes any legal liability or responsibility for the accuracy, completeness, or usefulness of any information, apparatus, product, or process disclosed, or represent that its use would not infringe privately owned rights. Reference herein to any specific commercial product, process, or service by trade name, trademark, manufacturer, or otherwise does not necessarily constitute or imply its endorsement, recommendation, or favoring by the United States Government or any agency thereof. The views and opinions of authors expressed herein do not necessurily state or reflect those of the United States Government or any agency thereof. 


\title{
IMPLEMENTATION IMPACTS OF PRL METHODOLOGY (U)
}

\author{
J. A. Caudill \\ J. F. Krupa \\ R. E. Meadors \\ J. V. Odum \\ G. C. Rodrigues
}

Nuclear Materials Planning Support

Westinghouse Savannah River Company

February 1993

APPROVED BY:

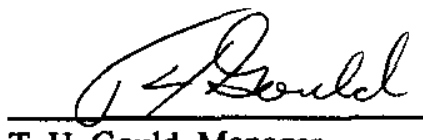

T. H. Gould, Manager

Planning Support and Analysis Department 


\section{Introduction}

This report responds to a DOE-SR request to evaluate the impacts which would result from the implementation of the proposed Plutonium Recovery Limit (PRL) ${ }^{1}$ methodology. The PRL Methodology is based on cost minimization for decisions to discard or recover plutonium contained in scrap, residues, and other plutonium bearing materials. Implementation of the PRL methodology may result in decisions to declare as waste certain plutonium bearing materials originally considered to be a recoverable plutonium product. Such decisions may have regulatory impacts, because any material declared or determined to be waste would immediately be subject to provisions of the Resource Conservation and Recovery Act (RCRA). In addition, the decision to discard these materials will have impacts on waste storage, treatment, and disposal facilities. Current plans for the de-inventory of plutonium processing facilities have identified certain materials as candidates for discard based upon the economic considerations associated with extending the operating schedules for recovery of the contained plutonium versus potential waste disposal costs. This report evaluates the impacts of discarding those materials as proposed by the F Area De-Inventory Plan ${ }^{2}$ and compares the De-Inventory plan assessments with preliminary conclusions from application of the PRL.

\section{Summary}

The impact analysis was performed for those materials proposed as potential candidates for discard by the De-Inventory Plan. The De-Inventory Plan identified 433 items, containing approximately $1 \%$ of the current SRS Pu-239 inventory, as not appropriate for recovery as the site moves to complete the mission of F-Canyon and FB-Line. The materials were entered into storage awaiting recovery as product under the Department's previous Economic Discard Limit (EDL) methodology which valued plutonium at its incremental cost of production in reactors. This value was approximately ten times higher than the energy equivalent value used by the PRL methodology. An application of Departmental PRL's to the subject 433 items revealed that approximately $40 \%$ of them would continue to be recoverable, or potentially recoverable, as product plutonium.

The primary issue resulting from the implementation of the PRL methodology is the lack of regulatory agreements for the management of TRU-mixed hazardous wastes that would result from PRL determinations. Several areas were identified that might have regulatory implications. These include: the lack of RCRA permitted waste treatment facilities for preparing materials for storage on TRU pads prior to disposal and the lack of analytical ability for RCRA characterization. In any event, material determined to be waste will require characterization, and possibly treatment, prior to its ultimate disposal at a facility like the Waste Isolation Pilot Plant (WIPP).

Any potential change to the status of these materials from recoverable product to waste should be addressed with the regulators in an a proactive manner, so that appropriate regulatory agreements or compliance schedules can be developed and implemented in a timely manner. Development of a regulatory perspective at the national level is desirable because the issues at SRS are shared by most processing and production sites in the DOE

1 William C. White, et al., Plutonium Discard Limit Study (U), NMP-91-31, September 29, 1992.

2 Author Unknown, $F$-Canyon and Associated Facilities De-Inventory Plan (U), NMP-PLS-920028, September 30, 1992. 
Complex and because it may be desirable to accumulate non-recoverable materials at sites with treatment capacity.

Adequate storage for characterized materials appears to be available on existing TRU pads.

\section{Comparison of the PRL to the Previous Plutonium Economic Discard Limit}

The PRL methodology was developed to provide a consistent basis for plutonium recovery vs. discard decisions. The methodology considers the total cost of recovery (including waste management costs) and total cost for discard, including required preprocessing. Recommended Departmental PRL's were developed for 24 categories of plutonium bearing materials based on cost data and other input from SRS and the Rocky Flats Plant. Sites are given the option of developing site-specific PRL's based on site costs and capabilities for processing and treating certain categories of materials. SRS based costs for PRL's on capabilities for plutonium processing in F-Canyon and FB-Line; however, plutonium processing capability also exists in $\mathrm{H}$-Canyon and HB-Line.

The primary differences between the PRL and the existing Plutonium Economic Discard Limit (EDL) methodology are: 1) valuing plutonium at its energy equivalent value rather than its reactor production cost, and 2) refinements in the details of processing and waste management costs. The EDL plutonium value is about a factor of ten greater than the proposed PRL value. Thus, the recovery-discard concentrations for Pu-bearing materials (i.e., $\mathrm{Pu}$ concentration above which recovery would be economically beneficial) determined by the proposed PRL method are greater than those determined under the EDL method. Consequently, some materials previously retained for recovery would be discarded under the new methodology. During the development of the proposed PRL method, it was recognized that changes to previous recovery-discard determinations might result in environmental and safeguards and security impacts.

\section{Study Approach}

The impact analysis was applied to those materials identified as potential candidates for discard by the F-Area De-Inventory Plan. The De-Inventory plan selection was based on an economic analysis that considered waste costs, processing costs and timetables for completing cleanout of FB-Line and F-Canyon. While this was not an exact application of the PRL methodology, it was considered an adequate first approximation for identifying materials for the impact analysis. Although plutonium residues are stored in cans, pails and shipping containers, this document refers to all individual storage units as "cans". The De-Inventory Plan recommended discarding 433 cans of plutonium bearing materials, primarily Central Scrap Management Office (CSMO) material received from other sites. These materials represent about $1 \%$ of SRS Pu-239 holdings. The remaining 99\% will be continue to be stored or will be recovered or stabilized and stored. Regulatory and down-stream waste management implications of discarding the 433 cans of plutonium-bearing materials were assessed. Additionally, a cursory analysis of recovery versus discard was made for these materials using the PRL methodology.

\section{Environmental Regulatory Issues}

Many of these materials have been stored for years. Most were entered into storage prior to the Department of Energy's 1987 byproduct rule making mixed waste subject to RCRA; some predate the 1980 effective date of RCRA. Based on the analysis in the De- 
Inventory Plan, SRS may be perceived as having moved very close to declaring these materials as waste. The scrap declarations for these plutonium-bearing materials provide insufficient detail on material characteristics to satisfy RCRA requirements; i.e., they do not give adequate description of the matrix containing the product plutonium in terms of toxic metals, TCLP toxicity, reactives, corrosives, or listed materials. Any plutoniumbearing material determined to be waste by the proposed PRL methodology will require characterization to satisfy RCRA requirements.

Permitted waste treatment facilities do not exist at SRS for preparation of materials for storage on TRU pads. A Hazardous/Mixed Waste Treatment Facility has been proposed for the 2005-2010 time frame. Although treatment of materials in canyon facilities for discard seems a logical choice, this option should be discussed with the regulators, SCDHEC and EPA, as it would likely affect the current definition of the waste generation boundary agreed to with the regulatory agencies. Currently, wastes become subject to regulation (i.e. are "generated") when they leave certain facilities or pass certain boundaries (e.g., liquid high level wastes become subject to regulation when they leave the canyon buildings and enter the waste headers and TRU solid wastes are generated when they leave the MAA [Material Access Area] following the last assay step). This would also require the canyon buildings to be permitted as hazardous waste treatment units. A typical Part B permit requires 2-5 years for approval at a cost in excess of one million dollars.

Overall, agreement with regulatory agencies is of primary importance before implementing the PRL methodology to avoid conditions of non-compliance. Areas for agreement with regulators include: 1) continued storage of materials determined to be waste in the F-Area vaults prior to characterization, treatment, and shipment to the TRU pads; and 2) treatment options for these materials to prepare them for storage on the TRU pads.

There is no direct NEPA impact from moving plutonium materials currently being stored in vaults to TRU pads for interim storage prior to shipment to a "WIPP-like" facility. However, a NEPA review would be required if new facilities are constructed, the materials are packaged for offsite shipment, or existing processes are modified to treat materials reclassified as waste. The Programmatic Environmental Impact Statement for Reconfiguration of the Nuclear Weapons Complex will address impacts of long term storage of plutonium materials.

\section{Waste Management Impacts}

Materials determined to be waste will have to be analyzed, repackaged, treated, and, if necessary, solidified to ensure that: 1) toxic metals are known and are the only RCRA hazardous materials present; and 2) there are no fines present in the materials (to meet TRU waste particle size requirements). The contents of some cans may be consolidated as long as curie content and fissile material limits are not exceeded. The final treatment would depend on agreements with regulators, prior process knowledge or results of characterization, and available treatment options.

The CSMO materials involved are probably heterogeneous, which will make effective sampling difficult. Characterization will be costly and will result in a significant personnel dose while obtaining samples. A previous study estimated a dose commitment of 100 man-rems and a cost of $\$ 1.6 \mathrm{M}$ to prepare the FB-Line vault holdings (approximately 1200 items) for characterization. If SRS can establish that the discarded 
plutonium bearing materials are TRU mixed waste containing only toxic, metals such as lead or chromium, these materials could be stabilized and consolidated in a permitted treatment facility, and stored on the TRU pads permitted for toxic metal containing TRU waste. These materials would be stored for shipment to a "WIPP-like" facility at some future date.

The current forecasts for TRU-hazardous waste generation at SRS are 1700 drums for 1993, 1500 for 1994 and 1500 for 1995 . Currently, about 3.6 permitted TRU pads with a maximum capacity of about 14,000 drums are available. Therefore, near term space is available for the materials in all 433 containers. Drums containing in excess of 0.5 Curies are required to be stored in concrete culverts. If the drums are required to be stored in culverts, their construction would cost about $\$ 100,000$.

Problems with drum assay equipment have also limited shipping of TRU waste on site. These problems will have to be resolved to move the proposed to-be-discarded material to the TRU pads.

In addition to the 433 cans containing $\mathrm{Pu}-239$, other SNM may be determined to be uneconomic for recovery and considered waste. The storage of discarded SNM at TRU pads could create security vulnerability issues. An assessment of potential vulnerabilities should be performed and procedures should be developed and implemented as necessary.

\section{PRL Evaluation Versus the De-Inventory Plan}

Application of the PRL methodology, which sets recovery limits at $\mathrm{gPu} / \mathrm{kg}$ bulk, is only possible for materials for which the $\mathrm{Pu}$ assay, bulk weight, and cost of processing are defined. There is currently no materials management information database containing the bulk weights for the inventory items. This information must be retrieved manually from a variety of sources and may be incomplete.

Based on limited information available from the FB-Line vaults, estimates of bulk weights were obtained for 69 cans. The PRL methodology was then used to determine the disposition of these materials. Additional information from the FY1992 Inventory Assessment and Nuclear Materials Disposition Report (IA/NMDR) ${ }^{3}$ allowed selecting dispositions for an additional 231 cans. For the remaining 133 cans there was inadequate information to establish a disposition.

For 126 cans, the PRL analysis based on either estimated bulk weights or information from the IA/NMDR gave bulk concentrations below the Departmental PRL: Thus, discard of these materials for eventual disposal in a "WIPP" like facility appears appropriate. Materials in nine of these cans were determined to be unprocessable with current flowsheets. Although most of these materials could be discarded relatively easily, two cans contain plutonium-depleted uranium-zirconium alloys with substantial amounts of plutonium. Disposition options for these alloys requires further development and evaluation.

The PRL analysis indicated that 79 cans are economically recoverable based on Departmental PRL's. Assuming that only uranium and plutonium metal or oxides are

3 F. E. McKay, et al., FY1992 Inventory Assessment and Nuclear Materials Disposition Report (U), WSRC-RP-92-1402-Vol-1, January 1993. 
present, the analysis indicated that an additional 95 cans are potentially economically recoverable.

Probable dispositions determined by the analyses described above are summarized in the following table:

\section{Disposition}

Economically Recoverable by PRL

Potentially Recoverable

Recommended for Discard

Indeterminate

Total

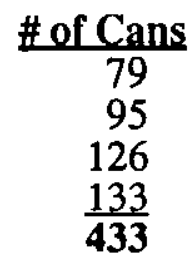

The results from this cursory PRL analysis validate the approach of assessing the impacts of the potential discard of plutonium bearing materials as proposed by the De-Inventory Plan as appropriate for an "order of magnitude" evaluation.

\section{Path Forward}

Agreements need to be reached on a national level with regulators on treatment of nuclear materials stored for recovery or for potential disposal. Such materials, if waste, may need characterization and possibly processing, to establish and treat hazardous constituents. Agreements would address schedules for analysis, treatment and/or processing, and storage of these materials.

A significant need exists at SRS to perform hazardous materials assessments for a variety of nuclear materials. Protocols need to be established with regulators as to required testing of materials formerly stored for recovery but potentially considered waste. Establishing these protocols will be helpful in clarifying the analyses, facilities and equipment required to ensure these materials are appropriately identified and characterized for disposal.

For those materials established by the De-Inventory Plan to be potential candidates for discard, SRS should move forward with all deliberate speed to characterize both the radio-isotopic and hazardous constituents of these materials and to determine and implement the appropriate disposition actions. Currently, Nuclear Materials Processing Division is developing a database to support nuclear materials management decisions. It is important that adequate resources are provided to complete this task. 